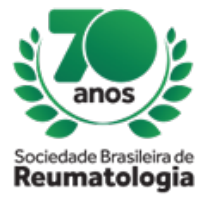

\title{
SPONTANEOUS PNEUMOMEDIASTINUM IN AMYLOPATHIC DERMATOMYOSITIS - A RARE MANIFESTATION
}

\author{
LAÍS DE VICO (UNESP, BOTUCATU, SP, Brasil), JOÃO PAULO CANAAN (UNESP, BOTUCATU, SP, Brasil), \\ SEAN HIDEO SHIRATA LANÇAS (UNESP, BOTUCATU, SP, Brasil), MATHEUS ZANATA BRUFATTO (UNESP, \\ BOTUCATU, SP, Brasil), JOELY CRISTINA DA SILVA TOLEDO (UNESP, BOTUCATU, SP, Brasil), LÍVIA \\ CÂMARA OLIVEIRA (UNESP, BOTUCATU, SP, Brasil), SULA GLAUCIA LAGE DRUMOND PACHECO (UNESP, \\ BOTUCATU, SP, Brasil), ANDREA DE ALMEIDA PEDUTI BATISTA (UNESP, BOTUCATU, SP, Brasil), LUIZ \\ EDUARDO VALENTE (UNESP, BOTUCATU, SP, Brasil), FÁBIO VICENTE LEITE (UNESP, BOTUCATU, SP, \\ Brasil), HENRIQUE PEREIRA SAMPAIO (UNESP, BOTUCATU, SP, Brasil)
}

\section{BACKGROUND}

Amyopathic dermatomyositis (AMD) is characterized by dermatomyositis (Gottron papules and heliotrope) cutaneous lesions in the absence of myositis. It accounts for $20 \%$ of cases of dermatomyositis. Intersticial lung disease may occur in $30 \%$. Pneumomediastinum, pneumothorax, and subcutaneous emphysema are rare complications with few cases described in the literature. Hamman's syndrome was discribed a case of AMD with complicated ILD by spontaneous pneumomediastinum.

\section{CASE REPORT}

$\mathrm{MB}$, male, 41 years old, previously health, rural worker, initiated a polyarticular inflammatory arthralgia associated with erythematous lesions on metacarpophalangeal, bilateral proximal and distal interphalangeal (gottron papules), elbow extensor erythema (gottron sign) and erythematous-violaceous upper bilateral (heliotrope) lesions associated with loss gain amount $30 \mathrm{~kg}$ in 6 months, in addition to dyspnea on moderate exertion. Absence of objective muscle weakness, normal muscle enzymes, electromyography without alterations and skin biopsy compatible with dermatomyositis, characterizing AMD. Negative paraneoplastic screening was performed. Autoimmune profile with ANA 1/80 nuclear fine dotted, Anti- Ro, La, Rheumatoid Factor, Anti citrulline antibodies, serologies for hepatitis B and C, HIV and Syphilis are negative. Chest tomography with interstitial infiltration suggestive of pulmonary fibrosis on discrete bases. We adoptted conservative treatment with prednisone $1 \mathrm{mg} / \mathrm{kg} /$ day and azathioprine $2 \mathrm{mg} / \mathrm{kg} /$ day. After 2 months, the patient was admitted to the ER with progressive worsening of dyspnea, severe retrosternal pain, dry cough, hoarseness, dysphagia, and a recent and progressive increase in the volume of the cervical region.

Eupneic, Haemodinamic stable Conscious and oriented. Pulmonar auscult with crepitations on 2/3 lower of the bilateral thorax. Emphysema subctunaeous was notted ate cervical region. New Tomography confirmmed: emphysema subcutaneous, Pneumomediastinum and progression of lung infiltrated. The hypothesis of ILD secondary to AMD and Hamman Syndrome has been explored. Evaluated by toracic surgery without indications of an invasive approach. He was pulsed with methylprednisolone $1 \mathrm{~g}$ for 3 days, followed by cyclophosphamide $0.6 \mathrm{mg} / \mathrm{m} 2$ / month.

After 30 days of hospital discharge, he was admitted to other service for sudden chest pain, evolving to death.

\section{CONCLUSION}

Spontaneous pneumomediastinum is an infrequent manifestation in systemic autoimmune myopathies and can be predisposed by ILD or previous corticosteroid therapy. We considered it important to report 
this case because of the rarity of the finding and to highlight it as a differential diagnosis of sudden dyspnea in these group of patients requiring rapid recognition, since it may be fatal if left untreated. 